Original Article

\title{
Matrix tool in the production of integrated care in the family health strategy*
}

\author{
Ferramenta matricial na produção do cuidado integral na estratégia saúde da família \\ Instrumento matricial en la producción del cuidado integral en la estrategia salud de la familia
}

\begin{abstract}
Maria Salete Bessa Jorge ${ }^{1}$, Diego Muniz Pinto ${ }^{2}$, Mardênia Gomes Ferreira Vasconcelos ${ }^{3}$, Antonio Germane Alves Pinto ${ }^{4}$, Rândson Soares de Souza ${ }^{5}$, Emília $^{2}$ Cristina Carvalho Rocha Caminha ${ }^{6}$
\end{abstract}

\begin{abstract}
Objective: To analyze how the matrix support in mental health contributes to the production of comprehensive care with an emphasis on the interrelationships between worker / user / family. Methods: Research with a qualitative approach that used the techniques of interview, focus group and systematic observation. Data analysis was based on critical hermeneutics. Results: Matrix support in mental health assumes pedagogical and technical assistance dimensions, which favor the interaction between primary care teams and specialist teams of the Center for Psychosocial Care (CAPS), ensuring territorially-based care, with interaction of different knowledge and practices. It further contributes to the redirection of the flow of users in seeking care for their health needs, articulating the levels of health care. The worker / user / family interrelationships are closer and allow better accommodation to the demands and bond of the team with the user and his family. However, difficulties such as consolidation of the matrix support, and the predominance of biomedical practice are noted. Conclusion: The matrix support contributes an expansion of the spaces of mental health care in the territory, opening living spaces, creation in the reaction of the worker / user / family, and thus configuring itself as a device for the production of integrated care. Keywords: Mental health; Comprehensive health care; User embracement
\end{abstract}

\section{RESUMO}

Objetivo: Analisar como o apoio matricial em saúde mental contribui com a produção do cuidado integral com ênfase nas inter-relações entre trabalhador/ usuário/família. Métodos: Pesquisa com abordagem qualitativa que utilizou as técnicas de entrevista, grupo focal e observação sistemática. A análise dos dados fundamentou-se na hermenêutica crítica. Resultados: O apoio matricial em saúde mental assume dimensões pedagógicas e técnico-assistenciais, que favorecem a interação entre equipes da atenção básica e equipes especializadas do Centro de Atenção Psicossocial (CAPS), assegurando um cuidado de base territorial, com interação de diferentes saberes e práticas. Contribui ainda, no redirecionamento do fluxo de usuários ao buscar atendimento para suas necessidades de saúde, articulando os níveis de atenção em saúde. As inter-relações trabalhador/usuário/familia são mais próximas e permitem melhor acolhimento das demandas e vínculo da equipe com o usuário e sua familia. No entanto, aponta-se como dificuldades para consolidação do apoio matricial o predomínio da prática biomédica. Conclusão: $\mathrm{O}$ apoio matricial contribui ampliando os espaços de cuidado em saúde mental no território, abrindo espaços de convivência, criação na reação trabalhador/usuário/família e por isso configura-se como um dispositivo para produção do cuidado integral.

Descritores: Saúde mental; Cuidados integrais à saúde; Acolhimento

\section{RESUMEN}

Objetivo: Analizar cómo el apoyo matricial en salud mental contribuye con la producción del cuidado integral con énfasis en las interrelaciones entre trabajador/usuario/familia. Métodos: Investigación con abordaje cualitativo en el que se utilizó las técnicas de entrevista, grupo focal y observación sistemática. El análisis de los datos se fundamentó en la hermenéutica crítica. Resultados: El apoyo matricial en salud mental asume dimensiones pedagógicas y técnico-asistenciales, que favorecen la interacción entre equipos de la atención básica y equipos especializados del Centro de Atención Psicosocial (CAPS), asegurando un cuidado de base territorial, con interacción de diferentes saberes y prácticas. Contribuye aún, en el redireccionamiento del flujo de usuarios al buscar atención para sus necesidades de salud, articulando los niveles de atención en salud. Las interrelaciones trabajador/usuario/ familia son más próximas y permiten una mejor acogida de las demandas y vínculo del equipo con el usuario y su familia. Entre tanto, se señala como dificultades para la consolidación del apoyo matricial el predominio de la práctica biomédica. Conclusión: El apoyo matricial contribuye ampliando los espacios de cuidado en salud mental en el territorio, abriendo espacios de convivencia, educación en la reacción trabajador/usuario/familia y por eso se configura como un dispositivo para la producción del cuidado integral.

Descriptores: Salud mental; Atención integral de salud; Acogimiento

\footnotetext{
* This article is a part of the project entitled "Network. for primary care as a link. for comprehensive mental health, with emphasis on matrixing", which was supported by the Ministry of Health. This study is original and was approved by the Ethics and Research Committee, State University of Ceara, UECE, Brazil (protocol 08622882-0).

${ }^{1}$ Full Professor, School of Nursing, UECE, Mental Health Area.

${ }^{2} M S_{c}$ student in Clinical Care, Nursing and Health Area, UECE; FUNCAP scholarship.

${ }^{3} M S c$ student in Public Health, UECE; CAPES scholarship.

${ }^{4}$ PhD student in Public Health, Wide association Course, UECE and Federal University of Ceará, UFC.

${ }^{5} \mathrm{MSc}$ student in Clinical Care, Nursing and Health Area, UECE.

${ }^{6}$ Undergraduate student, Nursing Course, UECE.
} 


\section{INTRODUCTION}

Interconnection between primary health care (PHC) and the substitute network for mental health care was established as one of the historical guidelines for consolidation and development of the psychiatric reform in Brazil. It repeats centralization of community- and territory-based devices as major equipment to overcome the existing iatrogeny in the hospital-centered mental health care ${ }^{(1)}$.

Thus, a search occurred to strengthen this interface by using the matrix support (MS), i.e., an action was observed either for a specialist in a particular producing unit to support the reference team in another one in more complex cases or to develop clinical guidelines, protocols, and projects ${ }^{(2)}$. Such practice can be used in the clinic for several possibilities, but in this study we will focus on the articulation between the mental health team (MS team) and those for family health (reference team).

In recent years, the interface between mental health and primary care, with focus on MS, has been the subject of a growing number of essays and considerations in Brazil. Several studies ${ }^{(3-9)}$ described MS (matrixing) as an innovative and very important arrangement for the formulation and development of proposals linking mental health to primary health care. It is primarily designed to contribute to the implementation of an expanded although singular clinic, promoting health and various therapeutic possibilities, favoring both co-responsibility among teams and horizontal communication, increasing the solving capacity of the teams regarding user health needs ${ }^{(7)}$.

Thus, MS in mental health directs basic care production because it reorients practices and operates in the space where events, manifestations, details and particulars, which are part of daily services, occur ${ }^{(10)}$. Furthermore, it proposes articulation between knowledge and practice (horizontally organizing the process), combining specialization and interdisciplinarity, and overcoming alienation, fragmentation, and biological technicism. Thus, it allows co-responsibility and reconstitution of ties involving reference team, matrix team, and users and their family members ${ }^{(7.11)}$.

In this context, the relational field placed in the therapeutic services is one of the dimensions of comprehensive care. In practice, the therapeutic services consist of revisiting and using care devices. In turn, these include user embracement, connectivity, co-responsibility, and accessibility, which are produced in the link between teams and users (provided by MS). This is possible since it facilitates a new way of practicing medicine, in which individuals and the socioeconomic and cultural context are included besides the disease.
Such dimension of care brings reflection on its comprehensiveness, which is present at the meeting, conversation, and attitude of professionals, who cautiously seek to know the needs of individuals regarding health, in addition to their explicit demands. Comprehensive action is also seen as a "relationship" between people, ie, it causes effects of positive interactions between users, workers, and institutions, which are translated into attitudes such as dignified and respectful treatment, with quality, embracement, and connectivity ${ }^{(12)}$.

Therefore, our goal is to discuss how MS produces health care, with axis on comprehensive mental health and emphasis on relationships involving worker/ user/family.

\section{METHODOLOGY}

This is a qualitative study because we intended to investigate the social phenomenon and its interface with the field of mental health ${ }^{(13)}$.

Two cities in the State of Ceará, Northeast region of Brazil, were the scene of the study. Particularly, the PSCC (General, Alcohol and other Drugs - AD and Children - I), FHS, and SCFH teams, which integrate the of mental health network in the cities.

Ninety-one individuals were the subjects in the study, and data collection was done in two periods (Oct 2009 - Mar 2010 and Jun 2010 - Oct 2010). As mentioned before, the participants were divided into six groups: Group I (24 individuals who work in PSCC and SCFH); Group II (19 individuals who work in FHS); Group III (17 users served by matrixing); Group IV (11 family members of these users); Group V (focus group with 12 individuals who work in the health area: PSCC, FHS, and SCFH), and Group VI (focus group with 08 users).

The high number of subjects in the study is due to the complexity of the subject under analysis, which comprises health workers, users, and their family members. The number of representatives in each group was determined by theoretical saturation, which determined interruption in the search for new participants when the final sample size was established, on the basis of redundancy and convergence of both meaning and significance obtained during collection and analysis of data ${ }^{(14)}$.

Semi-structured interview, observation of practices, and focus groups were the techniques utilized to obtain the discourses after participants signed the Term of Free and Informed Consent (TFIC). They were guided by ability to solve mental health problems within the primary care; communication relationship between worker, user and family; perception of matrixing; and flow of users on the health network; which served as script and theme. 
Analysis of empirical data was based on critical hermeneutics, and social praxis was the basis within the critical-analytical perspective. Assortment, classification, and final analysis of data were the operational steps ${ }^{(13)}$.

The results were consistent with the analytic configuration expected to understand the object of study, and were classified as discourses and comments, showing the thematic understanding by the study subjects of the category "Matrixing as a comprehensive care device for mental health in primary care: potential and weak points".

This article is a part of the project entitled "Network for Primary Care as a Link for Comprehensive Mental Health, with emphasis on Matrixing", which was supported by the Health Ministry/FUNCAP/CNPq. As required by the Ethics and Research Committee, UECE, the project protocol was submitted and received approval ( $\mathrm{N}^{\circ}$ 08622882-0).

\section{RESULTS}

\section{Matrixing as a comprehensive care device for mental health in primary care: potential and weak points}

In the reports, matrixing was evidenced as a device that links the PSCC team to that of FHS, ensures a specialized rearward favoring both co-responsibility of health teams and a territory-based care:

[...] in matrixing, people really can see a bit what multidisciplinary work is, where each of them has different knowledge, their points of view, and an action core in their professional context; they are there to share knowledge (Group II).

In my matrixing, I give my opinion; they listen to me and pay attention to what I say (Group III).।

Matrixing is perceived in the technical assistance and pedagogical dimensions of the discourses, through which it promotes interaction between different knowledge and reorients the network for health care:

Matrixing is a strategy for integration between primary and secondary care in mental health, which are the PSCC. It has several functions in the same activity, as screening (by which cases that should go to secondary or tertiary care in mental health are identified) teaching, training (so that primary care professionals can conduct milder cases), training for education of students, and also a link in the communication between services (Group VI).

This articulation [mental health and primary care] reduced the referrals to other places, reduced the flow to PSCC, and reduced the number of admissions to psychiatric hospitals (Group I).

Thus, this device was characterized as both facilitating tool (directing the flow in the network) and coordination provider between levels of health care:

Matrixing showed to be an effective device for articulation in network and bealth, allowing a co-responsible partnership between workers in different health services. Furthermore, an increase was observed in the diversity of therapeutic proposals for users, especially the territory-based ones, including walking, and collective and working activities (Observation of practice).

Use of relational techniques in the care process, such as user embracement, connectivity, co-responsibility and accessibility, was another important point observed in matrixing, which resulted in an increased solving of cases in mental health.

I feel happier, because I am here at the post, close to home, and I don't need to go to PSCC, and all the doctors said was successful in my life (Group VI).

When I come needing a post service, I never come back home disappointed. They always take care of me. It has already happened that my daughter was in crisis, and when I came here, they attended me soon. They already know what it is and they drop that person who is looking better and attend me soon with her (Group IV).

Embracement and connectivity were perceived as a horizontal relationship among all participants involved in matrixing, including that one between professionals and users/families:

I mark a few consultations, just for me to have a greater time, and I realized that the connectivity formed was so intense that, when we intended to transfer the patient to the PSCC, the patient did not want to go, and we observed a result: the patient believed in the treatment offered not only by me but by other professionals who were involved in the case (Group V).

The way my doctor treats me makes me come here, and I like to participate in all activities here, because I already came to this post, in the old one where I made the treatment, I abandoned everything I made there (Group III).

However, matrixing displays some weak points that hamper the provision of a comprehensive care, such as continuity of a positivist attention (predominantly pharmacological, physician-centered, including a drug-dependent vision of the society).

Matrixing only occurs if the physician is present, which highlights the fragility of matrixing in our city; we need to overcome this physician-centered view (Group I).

I think that medication is the only means for my brother to remain controlled; some physicians intend to withdraw or reduce bis medication, and I and the rest of my family do not accept this (Group IV).

I think that the comprehensive care could be better in matrixing because it is a very good and intelligent strategy to make it happen; unfortunately, we still have no appropriate professionals for all areas participating in this moment [...] we need to abandon the traditional pharmacotherapy, including because we can't stand, and we have to see the issue of groups, community and massage therapy, and invest in collective activities; this is very important (Group V).

In addition, weak points were mentioned, which are related to implementation and strengthening of matrixing (as a device in comprehensive care in mental health), 
due to non-participation and refusal of physicians to make a combined attendance and lack of management support to this practice.

Sustainable feeding is necessary, that which already exists because some things are somewhat asleep $[. .$.$] we spent some time$ working matrixing a lot in the units, we had courses and now it is much asleep; those who managed to keep it, it was kept, [...] we must sensitize other professionals; very often the local physician does not participate; in fact, he does not participate; sensitization of other teams [...] and so that matrixing may happen more systematically [...] commanding is the only thing lacking, determining, indicating which team goes to what post, and not having faults by car for this or that, as we see (Group II).

\section{DISCUSSION}

As reported in some studies, social exclusion, stigma, and confinement of subjects with mental disorder and/ or psychic suffering were widely disseminated by insane asyli who adopted the traditional view of mental illness (and their practice was based on a physician-centered health-care model, where the individual was fragmented into biological systems and its pathologies) contributed to a loss in the patient social value, influencing until now the way society still deals with issues related to mental health of people ${ }^{(3,15-16)}$.

However, mental health in Brazil is shifting towards new model of health care. It is a psychosocial model, that evolved since the reality influenced by the Sanitary Reform (in the two last decades of the twentieth century), it passed through a process of implementation and consolidation of the Unified Health System (UHS; Sistema Único de Saúde, SUS) and then, particularly by the Psychiatric Reform (which has been causing a continuous and consistent rupture in that psychiatric paradigm).

In this sense, Psychiatric Reform is understood as a process (transformation of practices, knowledge, and cultural and social values) that shows progress, but is still marked by impasses, tension, conflicts (personal relationships), and challenges in the everyday life of institutions and services offered by the network for mental health care ${ }^{(17)}$.

Facing the new imposed paradigms requires creating new strategies in the health care act, which may reflect a comprehensive understanding of health, taking into account the way of life of individuals. Thus, a new way to treat and embrace the subject in psychological distress in his/her daily life (and in his/her community space) is developed ${ }^{(18)}$.

Among these strategies, we have identified the need to strengthen health care (especially mental health within primary care) and its articulation with other substitute services in the net. Hence, this will be a way to transpose the logic of a referral (reference and counter-reference) that was not made by MS ${ }^{(1,7,19)}$.

As it can be observed in the empirical data, MS has two dimensions; one of them is characterized by the pedagogical support to the reference teams and the other by the technical assistance rearguard. This specialized technical support is available to a multidisciplinary health team to both expand its field of operation and qualify its actions in comprehensive care production ${ }^{(7)}$.

Regarding educational support, it occurs in mental health through a shared construction of knowledge and practice between a reference team (comprised of health care professionals, who are responsible for conducting an individual/family/community case) and a MS one (comprised of mental health experts, who add knowledge to the reference team and contribute with their interventions to increase the capacity of BHU to solve problems) ${ }^{(6)}$.

Thus, matrixing corresponds to knowledge and practice shared by these health workers. However, we emphasize participation of popular knowledge (provided by the user and family members) in building new health care devices (in response to the user needs) and articulation among these professionals (in producing therapeutic projects according to the uniqueness of each subject).

In the technical assistance dimension, MS can be understood as a device that favors comprehensive care because it is constructed on the relationships among employee, user, and family members and, in turn, between community and health services, rebuilding the health care network.

As can be seen, construction of a health care network covers more easily health needs of the population attended by UHS, in which MS is both a facilitator device (of flow direction in the network) and an articulation provider (between different levels of the health care system).

Thus, besides being the basis of different knowledge and practices, this device uses relational techniques (embracing, connectivity, and co-responsibility) to ensure access of users to health services and ability of these services to solve problems. Therefore, such reflection unfolds in the relational field. Furthermore, it can be seen that territorial insertion of FHS is broader than that of PSCC and, therefore, its work is much close to the community.

For this reason, the family health team must be able to deal with cases of suffering among their users, using the embracing device in their work processes to ensure services of higher quality. According to one study (20); accessibility and embracing are essential elements of care, so that professionals can effectively act on the state of health of both individual and community. 
Therefore, embracing is a device that can enable a new health practice, being understood by communication actions (acts of receiving and listening to people who seek health services, giving them appropriate answers to each demand at any path of the process), from reception and individual or collective attendance to external referral, return, remarking, and discharge ${ }^{(21)}$.

In this sense, MS implies the use of relational techniques to achieve a comprehensive care. Relational techniques are used during health care when subjective interactions are established, and they occur in the space of the therapeutic relationship where health professionals stay one in front of the other. From this perspective, dialogue is a field where techniques are molded. As reported earlier, dialogues (which mediate the health care work) shape not only the subject (through which the techniques operate) but also the very conversation (and how it is performed) ${ }^{(22)}$.

As it was shown, ease of communication among teams and between team and users/family permeates construction of connection and formation of affective ties, reflecting service quality (welcoming the user and establishing confidence during the meeting). In addition, the later search by users for solution of their problems with the reference worker is a mode of perception of the ties established between them.

Thus, construction of bond allows expanding clinic services, using other therapeutic resources (not only drugs). Health education, healthy lifestyle practices, and formation of caregivers (who can help the team in the care of complex cases in the community) are among these resources. This is done by moving negotiation from the care act to a consensus is reached between needs and responsibilities ${ }^{(23-24)}$.

In spite of the advances, a number of difficulties remain. They affect comprehensive care in the primary care level such as: a large unsatisfied demand, poor material conditions, insufficient qualification of health workers (which culminates with a poor service at the time of consultation when cold, unhuman, and indifferent relations are established), and persistence of the emergency care model, which still prevails in Brazilian primary health care (based on complaint-conduct, not on comprehensive care to the user nor on actions to protect collective life) ${ }^{(20)}$.

Despite these problems, connectivity is identified in FHS, especially by the team or by a reference professional (those who are responsible for conducting an individual, family, or community case), to increase the possibilities of constructing a link between professionals and users. Therefore, construction of connections depends on the particular mode of care, whereby health workers show their responsibility for the health of users and their family members ${ }^{(25)}$.
Thus, MS favors ability of health workers to solve problems in mental health care while their knowledge and practices are reconstructed. This is done by knowledge exchange (between the reference and matrix teams) and also restructuring an interconnected health care network. With emphasis on this reconstruction, the look of primary care to patients with mental disorders is expanded, favoring a comprehensive care to the user who seeks health services. In short, MS forms support and integration networks (26).

Hence, matrixing allows producing health through deep structural reforms to both achieving a greater ability to solve problems and reducing alienation of health workers regarding the ultimate goal of their work. In this perspective, specialized departments begin to act horizontally, offering specialized support to reference interdisciplinary teams. In other words, specialty meets the reference team to discuss cases. In this line, these teams are responsible for expanding the clinic and conducting medium and long term therapeutic projects; in addition, they promote connection and responsibility, avoiding the "logic" of unnecessary referrals ${ }^{(27-29)}$.

Despite the advances identified in the area of mental health in Brazil, the positivist paradigm of health care (in which predominance of biologic and pharmacologic aspects of the human being overlaps the social, psychological, and cultural ones) has not yet been fully overcome. Persistence of health biomedical aspects in the mind of some health workers weakens the health relational techniques thus disfavoring comprehensive care. As can be perceived in the discourses, professionals and users/family members keep a biomedical model of care production in their imagination.

Such valuation of biomedical knowledge conceives the process of social medicalization as a progressive expansion in the field of biomedical intervention redefining human experiences and behaviors as if they were medical problems ${ }^{(30)}$.

Our results also indicate some difficulty to achieve team work at FHS, mainly non-interaction of physicians in combined care (which causes fragmentation and disarticulation in work processes) and lack of management support to the new practice.

In order that a concerted work occur in a balanced manner, this new form of attendance must urgently become a natural and solidary way of working, which exceed personal arrogance, need of some professionals to exercise power over others, and tradition of care centralization by some of them. Health actions with relationships centralized in either worker or team shift the ill subject to the periphery of the process, thus denying the principles of comprehensive care, in which users and their health needs are in the focus ${ }^{(31)}$. 
Therefore, this context reflects the understanding that health services must be interconnected, forming a care network with institutions integrated into UHS. In this network, matrixing will act as an articulator between care levels, strengthening primary care (especially in mental health), beyond encouraging prioritization of soft technologies in health (as facilitator devices of comprehensive care).

\section{CONCLUSION}

The present study provided an approximation to the reality in the fields of study. Thus, we perceived that practices of workers who participate in mental health matrixing have contributed to health care production. These practices are revealing, especially in terms of (re)construction of the health care network, strengthening and effectiveness in the use of relationship techniques in health care (embracement, connectivity, co-responsibility, accessibility, and resolvability) as well as in redefining the therapeutic project for each user and its collective elaboration (workers/users/ families and greater interaction between community and health services).

\section{REFERENCES}

1. Vecchia MD, Martins ST. [The concept of mental care of a family health team from a historical-cultural perspective]. Ciênc Saúde Coletiva. 2009; 14(1):183-93. Portuguese.

2. Campos GW, Amaral MA. [Amplified clinic, democratic management and care networks as theoretical and pragmatic references to the hospital reform]. Ciênc Saúde Coletiva. 2007; 12(4):849-59. Portuguese.

3. Campos GW, Domitti AC. [Matrix support and reference team: a methodology for interdisciplinary health work management]. Cad Saúde Pública. 2007; 23(2):399-407. Portuguese.

4. Figueiredo MD, Campos RO. [Mental health and primary health care: the matrix support building a multicentric net]. Saúde Debate. 2008; 32 (78/80):143-9. Portuguese.

5. Figueiredo MD, Campos RO. [Mental health in the primary care system of Campinas, SP: network or spider's web?]. Ciênc Saúde Coletiva. 2009; 14(1):129-38. Portuguese.

6. Dimenstein M, Severo AK, Brito M, Pimenta AL, Medeiros V, Bezerra E. [Matrix support in Family Health Units: experiencing innovations in mental health]. Saúde Soc. 2009; 18(1):63-74. Portuguese.

7. Bezerra E, Dimenstein M. [CAPS and networking: constructing matricial support in basic health care]. Psicol Ciênc Prof. 2008; 28(3): 632-45. Portuguese.

8. Jorge MS, Sales FD, Pinto AG, Sampaio JJ. Interdisciplinarity in work process at a Psychosocial Attention Center]. Rev Bras Promoç Saúde. 2010;23(1):221-30. Portuguese.

9. Mielke FB, Olchowsky A. [Mental health in family health strategy: evaluation of matrix support]. Rev Bras Enferm. 2010; 63(6): 900-7. Portuguese.

10. Martines WR, Machado AL. [Care production and subjectivity]. Rev Bras Enferm. 2010; 63(2):328-33. Portuguese.
Hence, matrixing is configured as appropriate spaces for relationship between these subjects since it enables care production (in its spaces for coexistence), creation and establishment of emotional ties as well as spaces for exercising protagonism and citizenship of the human being in mental illness.

Therefore, matrixing must be strengthened in the primary care to serve as a tool to create an integrated care network, which allows interconnection among different care levels in the production of resolving care. Thus, matrixing will overcome biologicism/technicism and pharmacodependence of the care model still in force, and will help in transposing to a service that takes into account the social/cultural/economic/ spiritual and psychic aspects beyond the disease, confirming the principles and guidelines of UHS.

Regarding continuity and effectiveness of MS, however this strategy still faces difficulties such as: appreciation of the biological aspect to the detriment of other ones, insufficient training and education of managers in the municipalities and disrespectful behavior of some professionals in disregarding knowledge of other professionals, listening to each other and inter-relationship as essential devices to achieve comprehensive care.

11. Campos GW. Saúde paidéia. 3a ed. São Paulo: Hucitec; 2007.

12. Pinheiro R, Guizardi FL. Cuidado e integralidade: por uma genealogia de saberes práticas no cotidiano. In: Pinheiro R, Mattos RA, organizadores. Cuidado: as fronteiras da integralidade. Rio de Janeiro: CEPESC; 2006. p. 21-36.

13. Fontanella BJ, Ricas J, Turato ER.,[Saturation sampling in qualitative health research: theoretical contributions]. Cad Saúde Pública. 2008; 24(1):17-27. Portuguese.

14. Minayo MC. O desafio do conhecimento: pesquisa qualitativa em saúde. 11a ed. São Paulo: Hucitec; 2008.

15. Jorge MS, Randemark NF, Queiroz MV, Ruiz EM. [Psychosocial rehabilitation: perceptions of the Mental Health staff]. Rev Bras Enferm. 2006; 59(6):734-9. Portuguese.

16. Ayres JR. [Hermeneutics and humanization of the health practices]. Ciênc Saúde Coletiva. 2005; 10(3):549-60. Portuguese.

17. Brasil. Ministério da Saúde. Reforma psiquiátrica e política de saúde mental no Brasil: Conferência Regional de Reforma dos Serviços de Saúde Mental: 15 anos depois de Caracas. Brasília (DF): Ministério da Saúde; 2005.

18. Campos RO, Gama C. Saúde mental na atenção básica. In: Campos GW, Guerreo AV. organizadores. Manual de práticas de atenção básica: saúde ampliada e compartilhada. São Paulo: Hucitec, 2008. p. 221-6.

19. Jucá VJ, Nunes MO, Barreto SG. [The Family Health Program and Mental Health: difficulties and challenges for building a network]. Ciênc Saúde Coletiva. 2009; 14(1): 17382. Portuguese.

20. Ramos DD, Lima MA. [Health care access and receptivity to users in a unit in Porto Alegre, Rio Grande do Sul, Brazil]. Cad Saúde Pública. 2003; 19(1):27-34. Portuguese.

21. Santos AM, Assis MM, Rodrigues AA, Nascimento MA, Jorge MS. [Conflicting situations in the reception of oral health teams 
from the Family Health Program in Alagoinhas, Bahia, Brazil]. Cad Saúde Pública. 2007; 23(1): 75-85. Portuguese.

22. Ayres JR. [Care and reconstruction in healthcare practices]. Interface (Botucatu). 2004; 8(14):73-92. Portuguese.

23. Campos GW. [Paidéia and modelo of care: an essay on the reformulation of the way to produce health]. Olho Mágico (UEL). 2003; 10(2):7-14.

24. Santos AM, Assis MM, Nascimento MA, Jorge MS. [Bond and autonomy of the oral health practice in the Family Health Program]. Rev Saúde Pública. 2008; 42(3):464-70. Portuguese.

25. Campos GW. [An anti-Taylorist approach for establishing a co-governance model for health care institutions in order to produce freedom and commitment]. Cad Saúde Pública. 1998; 14(1):863-70. Portuguese.

26. Soares MH. [The insertion of the psychiatric nurse in the matrix support team in mental health]. SMAD Rev Eletrônica Saúde Mental Álcool Drog [Internet. 2008 [cited 2012 Set 10]; 4(2): [about 12p]. Portuguese. Available from: http:// www.revistasusp.sibi.usp.br/pdf/smad/v4n2/v4n2a06.pdf

27. Figueiredo MD. Saúde mental na atenção básica: um estudo hermenêutico-narrativo sobre o apoio matricial na rede SUS-Campinas (SP) [Dissertação]. Campinas: Universidade Estadual de Campinas; 2006

28. Campos GW. [Local reference teams and specialized matrix support: an essay about reorganizing work in health services]. Ciênc Saúde Coletiva. 1999; 4(2):393-403. Portuguese.

29. Jorge MS. Práticas de abordagens terapêuticas grupais dos trabalhadores de saúde na produção do cuidado em saúde mental, Fortaleza/CE. Relatório final da pesquisa. Fortaleza: GRUPSFE-UECE: 2009.

30. Tesser CD. [Social medicalization (II): biomedical limits and proposals for primary care clinics]. Interface (Botucatu) .2006; 10(20): 347-62. Portuguese.

31. Saupe R, Cutolo LR, Wendhausen AL, Benito GA. [Competence of health professionals for interdisciplinary work]. Interface (Botucatu). 2005; 9(18): 521-36. Portuguese. 